\title{
THE EFFECTIVENESS OF USING PHONICS INSTRUCTION AND STORYBOOKS IN ENGLISH READING CLASSES TO IMPROVE STUDENT PARTICIPATION
}

\author{
Naning Tri Wahyuni, Endang Fauziati and Mauly Hikmah \\ English Language Study \\ Magister Program, Muhammadiyah University of Surakarta \\ Jl. A. Yani Pabelan Kartasura Tromol Pos I Surakarta 57102 Phone (0271)717417 \\ E-mail: naning.ariyanto@gmail.com, endang.fauziati@ums.ac.id \\ Mauly.Hikmah@ums.ac.id
}

\begin{abstract}
The purpose of this study is to examine the effectiveness of instructional methods based on phonics instruction in reading classes to improve students participation therefore they can develop to their maximum potential. Using qualitative tools of observation, documentation and interview, this research was focusing the inquiry on investigating students' reception to the phonics instruction model, observing their participation in the classroom activities, also investigating instructional methods which attract students to more actively contribute in learning activities. The finding shows that the reception of students to the model was good and they showed much eagerness in following the program. Further investigation revealed that students keen to participate more in the classroom activities especially in certain activities with the use of sound sheets, sound book, flash card sheets, word box sheets, songs, games and storybooks. However, there were two challenges identified during 16 weeks running the study; the lack of teachers'skill in delivering this method efficiently also the limited collection of English story books in school. Hence, to improve the effectiveness of the use of phonics instruction in reading classroom, firstly, training for teachers would be needed to deliver the method effectively, secondly, considering the fact that school still have limited collection of English story books or any English books, the collaboration with government agencies or other promising bodies could be done to help in providing more collection of storybooks in school.
\end{abstract}

Keywords: Phonics instruction, reading classroom, students' participation

\section{INTRODUCTION}

Learning process in the classroom without active participations from students could be pretty boring. In the other hand, student participation could create more dimensional and engaging classroom activities which eventually could lead to the more effective learning processes. When students participate, they actually give teacher valuable information on what they know and they understand about a concept. Additionally, class discussions prompt students to listen to another's point of view and adjust their thinking accordingly. Participation requires students to use high-level thinking skills, such as analysis and evaluation skills. For the example, when students come to disagreement in discussing things, they actually are going 
beyond simple recall skills and showing a deep understanding of a specific content. In this way, students would also share their views and knowledge and even would be able to give feedback to each other.

In world widely educational learning approach, students' participations are not really new proposed idea. Over decades, the modern instructional approach of student-centered learning has put strong emphasized on the students' participation in designing classroom practices. Student-centered learning focuses on students' interests first and acknowledges students' voices as central to the learning experience which basically stimulates students to get involve actively in the classroom activities. Collins and O’Brien describe this approach as:

Student-centered instruction [SCI] is an instructional approach in which students influence the content, activities, materials, and pace of learning. This learning model places the student (learner) in the centre of the learning process. The instructor provides students with opportunities to learn independently and from one another and coaches them in the skills they need to do so effectively. The SCI approach includes such techniques as substituting active learning experiences for lectures, assigning open-ended problems and problems requiring critical or creative thinking that cannot be solved by following text examples, involving students in simulations and role plays, and using self-paced and/ or cooperative (team-based) learning. Properly implemented SCI can lead to increased motivation to learn, greater retention of knowledge, deeper understanding, and more positive attitudes towards the subject being taught (Collins \& O'Brien, 2003).

The idea of students' participation above essentially is in line with the continually and widely campaigns about children rights by UNICEF. One of the rights which have been promoted is Participation Rights. The Convention on the Rights of the Child (CRC) states that children have the right to participate in decision-making processes that may be relevant in their lives and to influence decisions taken in their regard-within the family, the school or the community. The principle affirms that children are full-grown persons who have the right to express their views in all matters affecting them and requires that those views be heard and given due weight in accordance with the child's age and maturity. It recognizes the potential of children to enrich decision-making processes, to share perspectives and to participate as citizens and actors of change. The practical meaning of children's right to participation must be considered in each and every matter concerning children (UNICEF, 2014).

Considering the goal of education set up by UNICEF's Convention on the Rights of Child that children's education should develop each child's personality, talents and abilities to the fullest, hence creating meaningful and engaging classroom activities are very critical in learning process. Many researches have been done so far to create interactive learning environment to improve students' participations and positive learning experience. In the end, those researches reveal that in creating constructive learning environment, it cannot be denied that teachers or any other educational practitioners must be considering the nature of children in learning, the instructional approach in learning which accommodate the needs of students to get constructive learning experience, the interactive instructional methods and the last is the engaging instructional materials which attract students to participate more and more (Wahyuni, 2015).

Children like playing and learn things while playing. The implication to language teaching could be through games, by definition that game is an activity with rules and a goal with the element of fun. The emphasis in the use of games for language learning is on successful communication rather than on correctness on language, and games should be regarded as an 
integral part of the language syllabus (Hafield, 1985).

Children talks about anything they have known and currently happen surround them. Adults both observe and enforce the cooperative principles when they talk to young children; they say something relevant and talk about the child world. They encourage children to take their turns and make their contributions to the conversation. They make sure that children make their contribution truthful by correcting them (Clark and Clark, 1977: 322).

Children like engaging activities; they will understand better and grasp the meaning of things quicker when they have seen some objects with them. They retain the meaning better by seeing the object and the things which is associated with it. For this reason, teacher should expose the students to real life situations. Other strategies can be applied to support this method by using visual aids, picture and images, since visual are more vivid and attractive than words. Thus, in teaching and learning process, pictures should be integral part of every teacher's professional equipment (Ernestova, 1988: 278).

Another issue that should be brought in this discussion is student-centered learning. It is also known as learner-centered education, broadly encompasses methods of teaching that shift the focus of instruction from the teacher to the student. In original usage, student-centered learning aims to develop learner autonomy and independence by putting responsibility for the learning path in the hands of students (Jones, 2007). Student-centered instruction focuses on skills and practices that enable lifelong learning and independent problem-solving (Young and Paterson, 2007). Student-centered learning theory and practice are based on the constructivist learning theory that emphasizes the learner's critical role in constructing meaning from new information and prior experience. In classroom activities, student-centered learning requires students to be active, responsible participants in their own learning and with their own pace of learning (Johnson, 2013)

Student-centered learning may also refer to instructional methods that recognize individual differences in learners. In this sense, student-centered learning emphasizes each student's interests, abilities, and learning styles, placing the teacher as a facilitator of learning for individuals rather than for the class as a whole. The theoretical background for this method is actually coming from the work of theorists such as John Dewey, Jean Piaget, and Lev Vygotsky, whose collective works focused on how students learn.

Over decades, plenty of researches have been specifically dedicated to find the best way to teach children to read. Morag Stuart pointed out in his research paper that in order to find the best way to teach young learners, experts and practitioners have to understand the processes being employed by skilled readers first.

"Major theories of how skilled readers recognize, understand and pronounce written words include processes for phonological recoding (i.e., translating segments of print to their corresponding segments of sound) and processes by which direct access is achieved from printed words to their meanings. If these are the processes employed in skilled reading, then these are the processes which children learning to read must develop in order to become skilled readers (Stuart, 2006: 19).

International reading Association did thoroughly review to the most collected research reports over decades, they eventually come across the most evidences that teaching all children to read require that every child receive an excellent reading instruction. Moreover, they pointed out that the primary focus in teaching reading should be in reading instruction which teach students to make association between the sounds in English spoken language and the written letters which represent the sounds. In brief, key areas of instruction must include phonological 
awareness, phonemic awareness, vocabulary, comprehension, and fluency (International Reading Association, 2000: 31) which is later called phonics instruction.

Reading programmes which accurately follow the systematic phonics principles teach students the Alphabet code directly, systematically and discretely. An alphabet code is the reversible relationship between the phonemes (the smallest discernible sounds in spoken words) and the graphemes (spellings) (McGuinness, 2004: 5). Henceforth, phonics for reading starts with introduction of the 26 alphabet letter names and sounds. Later, children are taught to associate a spoken sound with a letter or letter-pair. This process is known as phonemic awareness or letter/sound associations. As soon as the letter/sound associations have been introduced, they are immediately placed in words that reflect common English configurations. Students are explicitly taught a decoding strategy in which they say the sounds for each grapheme (letter(s) that represent a sound), say the sounds quickly, and then pronounce the entire word. Through focused instruction students repeatedly sound out and blend words. A whole of this process is called decodable words (UK National reading panel, 2000). The last process in phonics instruction is relating these letter/sound associations and also reading word to the larger scale of reading printed data which consist of a lot of words or sentences in particular context, e.g. book reading or story reading.

Teaching phonics in the context of storybooks could be expected to endorse the use of phonic knowledge during reading activities because decoding is embedded in the context in which it is used, thus stimulating generalization of taught knowledge. It also might extend children's understanding that mastering the alphabetic principle can help children in retrieving the meaning of printed language, hence it also encourage them to understand the functional and the benefits of learning to decode (Adams, 1998). Further, systematic instruction in beginning phonics embedded in story reading could be expected to nurture children's ability to read words in related text and to raise comprehension by evolving understanding of the utility of word decoding skills for comprehension.

Story reading is often significant and inspiring to children since it addresses interesting topics and also concern to child's developmental needs. Children's books which light up some moral aspects such as friendship, bravery, loyalty, happiness, sadness, exclusion, courage, etc. empower children to make meaningful connections. Book reading also enables children to make sense of their world and to expand their understanding of life and the human condition Story narratives enhance children's understanding of human character and present models for their own interactions (Appleyard, 1990). In addition, In a second and foreign language class, book reading will be also valuable for learners to explore the ethics and criteria of the target language culture and compare them to those in their own environment. Thus this can help them in comprehension skills.

\section{RESEARCH METHOD}

This study was working under the qualitative framework. Qualitative data through observation, interview and documentation were gathered to investigate students' reception to phonics instruction models, to observe their participation in learning activities and to examine the instructional models which draw students to get involved keenly in the classroom activities.

Subject of this study was third grader students at Al Abidin International Islamic School. There were 30 students who participated in this study with the age between eight to nine years old. The techniques used in obtaining data were observation, documentation and interview.

The classroom observation applied in this study was semi-structured in nature which was hypothesis generating rather than hypothesis testing and was also reviewing the observational 
data before suggesting an explanation for the phenomena being observed. Working towards the objective of study, this observation was aiming to investigate students' reception and students' participation in the classroom activities and what kind of activities which attract students more to contribute to the learning activities. To capture more details information needed, the observation was conducted in every session of reading classes during 16 weeks of running the program.

Documents and records are another rich source of information. In this study, document refers to any written materials, pictures and videos which covered all the information relate to the learning processes of students and classroom activities where students were getting involved. The recorded materials came from recording reading activities in the reading session and also field notes prepared by the researcher. Field notes were written notes made in the research setting, recounting what the researcher sees and hears and understand. All the collected documents above were analysed and discussed in relation to the findings gathered through classroom observations and interviews.

The present study used semi-structured interview to gather detailed and focused information about students 'reception to the instructional methods and classroom activities they got involve to. This interview allowed freedom for students to speak more issues in connection to the classroom models and the problems they faced in following the program and the classroom activities.

All the qualitative data gained from observation, documentation and interview were verified by using triangulation data in terms of both sources and methods. First, triangulation involved the use of multiple data sources in order to obtain re-occurring results from different sources. Each data source has its strengths and weaknesses. Therefore, all the data from multiple sources of participants, time and sites were compared to provide a comprehensive evaluation. The participants in here were 30 students from the third grader with eight students being interviewed personally. Second, triangulation also involved comparison of multiple methods of data analysis by incorporating a combination of observations, interviews and document analysis to cross-validating the findings. Additional triangulation also was done by comparing participants' verbal statements against their actual performance.

Using descriptive qualitative approach, all of the data were gained through interviews, class observation and school documentations. The qualitative data served as a guide towards the exploration of issues in students' receptions with the program and students' participation in classroom activities. Observation notes, transcripts of interviews and video recordings of classroom activities were analysed in order to identify emerging patterns in the receptions of those involved in the study. Further, the data from this approach will be analysis in the form of description to support the discussion in analysing the investigation.

\section{RESULT AND DISCUSSION}

This study was done in one semester in Al Abidin international school of Surakarta to observe students' reception and participation to the program and kind of classroom activities which attract more for students' participation.

Students who participated in this study signed to join with 16 weeks of reading program with the teaching instruction based on phonics and storybooks program. Below the details of syllabus of the program and classroom procedures: 


\section{Syllabus of the Program}

\begin{tabular}{|c|c|c|c|c|c|}
\hline \multirow{2}{*}{$\begin{array}{l}\text { Materials } \\
\text { and } \\
\text { classroom } \\
\text { activities }\end{array}$} & Letters an & ds recognition & Blending & \multirow{2}{*}{$\begin{array}{c}\text { Identifying } \\
\text { sounds in } \\
\text { words }\end{array}$} & \multirow{2}{*}{ Tricky words } \\
\hline & $\begin{array}{l}\text { Sound } \\
\text { groups }\end{array}$ & $\begin{array}{c}\text { Classroom } \\
\text { activities }\end{array}$ & $\begin{array}{c}\text { Classroom } \\
\text { activities }\end{array}$ & & \\
\hline
\end{tabular}

Week $1 \& 2 \quad$ S a t i p n

Week 5 ai j oa ie ee or
Hearing the sounds after they have been spoken by teacher/audio/ song

\begin{tabular}{cc}
\hline Week 3 & c/kehrm d \\
\hline Week 4 & goulfb \\
\hline
\end{tabular}

\begin{tabular}{cc}
\hline Week 6 & $\begin{array}{c}\text { Z w ng v little } \\
\text { oo long o }\end{array}$ \\
\hline Week 7\&8 & $\begin{array}{c}\text { y x ch sh } \\
\text { voiced th } \\
\text { unvoiced th }\end{array}$ \\
\hline Week & $\begin{array}{c}\text { Qu ou oi ue } \\
\text { er ar }\end{array}$ \\
\hline
\end{tabular}

Storybooks

letters games,

flash cards

Reading
Hearing the words after sounds have been spoken by teacher or audio

Practising blending techniques in simple words (c.v.c words)

Beginning words box and sounds box activity

Classroom techniques: Words box sheets, Words games, flash cards
Identifying
the sounds in words, E.g.
Is there any
's' in 'sad'?
Where is
'd'? in the
beginning/ middle/ end
of the word?
Hearing the words after sounds have been spoken by teacher or audio
Learning to
sound out,
blend and
spell the 10
tricky words
for each
meeting
Reading tricky
words using
flash cards,
words box
sheets

Practising blending

4/+ letters words

Beginning words box activity

Reading the short story (Oxford reading tree -

Phonics series level by level depend on the sounds and blending which children already learnt
Whole class calling out sounds in given word, e.g. ant, then holding up a finger for each sound and counting

\begin{tabular}{|c|c|c|c|c|}
\hline $9 \& 10$ & er ar & & scheme & \\
\hline $\begin{array}{c}\text { Week } \\
11 \& 12\end{array}$ & $\begin{array}{c}\text { Alternative } \\
\text { spelling } \\
\text { vowels sound }\end{array}$ & $\begin{array}{l}\text { Practising } \\
\text { alternative } \\
\text { spelling vowels } \\
\text { sounds }\end{array}$ & $\begin{array}{l}\text { Hearing the words after sounds have } \\
\text { been spoken by teacher } \\
\text { Practicing more words together with } \\
\text { class }\end{array}$ & \\
\hline $\begin{array}{l}\text { Week 13- } \\
16\end{array}$ & $\begin{array}{c}\text { Intensive } \\
\text { Reading } \\
\text { Classes }\end{array}$ & $\begin{array}{l}\text { Reading } \\
\text { classroom: } \\
\text { storybooks }\end{array}$ & Individual and group reading & $\begin{array}{l}\text { Classroom } \\
\text { discussion }\end{array}$ \\
\hline
\end{tabular}

Practising consonants blends and and digraphs

Practising blending regular words with consonant blends

Following up words box and sounds box activity

Introducing characters from reading scheme 


\section{Classroom Procedures}

There were five steps of teaching which was delivered in the class: letters and sounds recognition, blending, identifying sound in word, learning tricky words and finally book reading. Each step of teaching was delivered in direct instruction using traditional classroom procedures of PPP model; presentation, practices and production.

\section{Letters and Sounds Recognition}

Letters and sounds recognition was taught by following the order of letter sound groups mentioned in syllabus of the design above. Each group contains of six letters that children have to master in a week or two for both of the letters and its sounds. In total there were 42 sounds in English from 26 alphabet letters that children must learn and master in 12 weeks following the program.

In presentation stage, teacher started with sounding out each letter and asked students to follow by sounding the letter out. Teacher also used sounds-phonics audio and phonics songs to make sure that the letters are pronounced correctly. Below the sample of the instruction in classroom activities that teacher used in explanation:

"Today we are going to learn the sound of 's'. Can you hear the sound of 's' in snake, sun, sand. Come on! Try to make the sound s s s snake. It is important to know the 's' sound because it will appear in many words and books you will read".

Then students were encourage to sound the "s" letter and use them as well in some sample words with this sound in them to figure out how this sound works in words. The sample words must be containing "s" sound in the beginning (such as sun, snake), in the middle (such as sister) and in the end (such as twist, yes), hence students can work out how "s" sound contributes in word formation. Teacher used flash cards and sound sheets in teaching.

This presentation stage later was followed by practices where students did practicing the sounds first with the class under teacher guidance and did practices individually later. Students used flash cards and sound sheets to practice in group or individually under teacher's supervision. In this level of letters and sounds recognition, students did not start to learn word formation yet. They were only encouraged to recognize each letter in its sound and also recognize them when they were in words. The last stage was production where all students were hope to be able to sounding the target of letters out and recognize its letter in words.

\section{Blending}

After students were able to sounding out the target letters, teacher then taught them how to blend these sounds altogether to form words using from the simple C.V.C words (Consonantvocal-consonant: sun, tip, pan, etc.). The blending basically is process of saying the sounds in a word and then running them together to form the sounds of word, e.g. $p$-a-n for pan. This blending step will follow the order of the sounds groups. For example, children were first taught the sounds for the letters 's', 'a', 't', 'p', 'i', and 'n'. They were then taught to blend these sounds into words (e.g. 'pat', 'sit', 'nap', 'tin'). See table two in the chapter two for more samples of words blending.

In the presentation stage, teacher chose from simplest word of three letters words such as tin or sit, sound the sounds out and run the sounds first slowly then quickly until it sounded that the formation of sounds have made the sound of its word. For the example teacher said:

"Today we are learning to read word. Do you know that the sounds that you have learnt 
can make some nice words? Do you know the word "sit"? What sounds are in the word "sit"? yes, sit comes from s-i-t. Now try to run these sounds together, first slowly then quicker and quicker. Follow me!"

Classroom observation showed that Indonesian young learners clearly had known many simple words in English and able to pronounce them well. However, blending taught them how those word sounds actually come from. The principle of blending in running the sounds together to form words is hope to help students to work out when they meet new words hence they able to figure out how pronounce them properly by applying their blending skills.

Later in practice stage, students were encourage to horn their blending skill by starting from the simple words of 3 letter words (e.g. $p-a-n, n-a-p$, etc.), then move to 4 simple letter words (e.g. s-i-n-g), followed by the more difficult one of $4+$ letter words (e.g. s-i-n-g-e-r), then to the advanced words using the order of letter sound groups (e.g. sound "oi" in o-i-n-tm-e-n-t).

In the production stage, students were hope to be able to pronounce word correctly without blend them loudly. They used word box sheets, sound sheets, flash cards and words game to play with. They even were encouraged to read storybook under teacher's supervision to horn their blending skill.

\section{Identifying Sounds in Words}

The ability to hear the sounds in words called phonological awareness. For the example, when students heard the word "pin", students could hear the sounds " $p-i-n$ ". From the classroom observation, it definitely helped students not only in memorizing word and spell it properly, but also to understand how phonics works in order to form word from letter and sounds association.

In the presentation stage, teacher showed many words from the simplest one (c-v-c words) to the longer ones (depend on the sound groups students already learnt) and asked students to point out certain sounds in the words. For the example:

"Today, I have "sun". Can you mention the sounds on it...Yes, "s-u-n". Where do you find the "u" sound?....yes, in the middle. Now, I have "Umbrella". Where you can find the "u" sound?...yes, in the beginning of the word. Now, how about "sister", will you please sound all of the sounds on it? Finger up and count them!"'

This stage then followed by more practices from children to sounding out the sounds in the sample words using flash cards and word box sheets under teacher's supervision. Then in the production stage, students were hope able to sound out all of the words provided by teacher and later followed by story book reading to enhance their skills. Students did in group and sometimes individually appointed by teacher.

\section{Tricky Words}

Students were more able to read regular words when they have knowledge of letter sounds and can relate to sounds and its letters. However, tricky words cannot be sounded out or spelt out correctly by listening for the sounds in them. Most of tricky words belong to irregular words. Thus these words have to be learnt individually.

In presentation stage, students are asked to look carefully at the words, pay extra attention to them and put them in to their memory. Students were also encouraged to recall their knowledge of letter sounds correspondences and their blending skills asked to figure out how to sound the words correctly. Later, when they pronounce them wrong, teacher showed how to 
pronounce them correctly. In this way, students were able to figure out that some words do not work and cannot work just like the others, they were called tricky words. Hence these kinds of words need more attention in memorizing. Below sample of class instruction:

"Now, you all have learnt many nice words. But, you know that there are some a bit naughty words that do not follow the normal blending way. They were called tricky words, since they will trick you more to learn. For the example, do you know the word "one", how do you spell it? How the sounds work? Yes, the sounds seem do not work well in the word "one". Now, for this word, you have to memorize both the sound and its letters as well. So, you will be able to sound it out, to spell it out and even to write it down. Let's practice more...!"

In this program, the tricky words started being introduced after the third group of letters have been taught. Students learnt 10 new irregular words a week. Students were encouraged to look at them carefully, and identify the irregular part of them. For example, the word "are", the "ar" letters were pronounce regular, but the "e" has been lost in the word pronunciation which is irregular. Students then were taught to sound the word correctly and memorize them.

In the practice stage, students were encourage to read more tricky words, work them out their self then later teacher corrected them when they did make wrong. Word box sheets and flash cards were used to help in learning tricky words. Children eventually have to master all the tricky words given by the teacher in the production stage.

\section{Storybooks}

There were three steps of classroom activities in book reading; teacher read the book to students in reading time or after phonic session in combining instruction with phonics class. Later, students read the book in group to promote class interaction, and finally the students read the book their self to enhance their skill in using phonics for reading.

In the first step, teacher read the same book aloud to the class through the week or until the teacher saw that students did not have problems anymore in word reading and comprehension, then moving to a new book when it was considered that students were ready to. To encourage pupils to focus more on the text and less on illustrations, the teacher, while reading to students, often followed the line of text with fingers or and stopped the reading at times to explain some difficult words to blend or when found new words and discussed with the class some decoding aspect of the text, such as a consonant blend. Teacher read the book to students after each session of phonics and students supposed to see the printed words clearly and engaged with it not just in terms of letters and sounds associations to sound words in speech but also in term of meaning as well.

In the second step, when students showed more interest and confidence in reading activity, they started reading the book for themselves in groups. The book chosen began from the shortest ones and increased gradually depends on the current level of ability of students in decoding words. Teacher encouraged students to apply their phonics skills, praised them when they did correctly and helped them when they did in wrong way. Every student in groups had to be actively participated and discussed the issues in the book with their peers in group.

In the third step of reading, children read the book individually under the teacher's supervision. Teacher sometimes asked one student to go to the front of the class and read the book for a whole of the class. Teacher encouraged the similar decoding skills to students and promoted other students' participation in discussion of the topic and also on the decoding skills. Teacher also sometimes asked students to take the book home to read with parents. 
Later, in the next meeting, teacher would ask students to re-read the book in front of the class or individually to assess how far they were able to apply their phonics skills and comprehended the texts.

\section{The Discussion}

There were two things which were investigated in this study, first the students' reception and participation in the class and second, classroom activities which engaged students in to more active participation. The details of findings are discussed in the following details.

\section{Students' Reception and Participation in the Class}

During classroom activities, students' reception was good. They felt not enough confidence to read the texts and stories at first, however with guided reading from teacher, their confidence and eagerness rose gradually. They did a lot of mistakes in pronunciation; however they keen to learn the correct ones. As for comprehension, they mostly still worked based on picture clues in guessing the meaning. However, since the reading materials which had been used in this program (Oxford reading tree - phonics series), had been developed gradually from the simple and short texts then moved forward steadily, they finally found the books were easy to understand progressively. Below some quotations from students:

Researcher: "Do you like the book, Z?

Student Z: "Yes, I like it. Ini opo to, Miss? Aku juga belajar phonics di ODI. Tapi ini beda, ini ceritanya bagus-bagus".

Researcher: "Do you like the book, A? tahu artinya ndak?"

Student A: "Yes, sedikit menebak-nebak ceritanya, dari gambarnya, Miss. Boleh pinjem bukunya, Miss?"

Researcher: "Do you like reading, H. Do you like the books?

Student H: "Yes, I like reading. Ini bagus-bagus. Dari Inggris ya, Miss. Bisa pinjem ya?"

In overall, students' reception to the model was good. They felt phonics instruction was interactive learning model. The materials were easy to follow for students. Combined with book reading program, the systematic instruction looked great and promising. Students were eager to follow the fully program especially with the promising of plenty story books, nice songs and activities.

\section{Interactive Instructional Models}

There are some classroom activities which attracted students more in class participations, below the details:

\section{Sound Sheets and Sound Book}

The sound sheets provide the starting point for this teaching. There are 42 sounds in the sound sheets. In learning the letter sound, first teacher shows to children how to sounding out the specific letter. For example, the sound 's', and later asking the children to copy and follow the sound ' $s$ '. Then, teacher show the sample of this sound in word, such as ' $\mathrm{s}$ ' in the words snake, sun, sheep, etc.

Sound sheets has plenty activity. For each of the letter sounds there is suggested storyline which teacher free to develop. It also contains an action and worksheet. The worksheet has a picture relate to the story and the sound being learn for children to colour in. further, the 
sheets also show other words that containing the sound. All of the sound sheets contain the letters and sounds which have been learnt are collected to make sound book. Thus students can always remember the sounds they have learnt later. During the program, the students showed eagerness in collecting sound sheets and compiled them to make sound book which they could bring home and showed to their parents. The sample of sound sheets and sound book can be viewed in appendix 2 .

\section{Flash Card Sheets}

There are two kinds of flash card sheets: sound flash card sheets and word flash card sheets. Sound flash card sheets are very useful to help to mastering the letter sounds, while word flash card sheets are valuable to become skilled at words reading. The flash cards are usually used as a way for reinforcement. It means that teachers use these in high repetition in every lesson to remember the sounds or words they have been taught to children.

Once the children have been taught the letter sounds from the sound sheets, they will need to become very fluent at recognising the sounds. Flash cards for each letter sound are very useful for this and these should be used for most of the days to remember the sounds of the letters. Every time teacher holds the cards up, students call the sound out. The same way works on word flash cards also. The flash card sheets can be added to the sound books own by every student.

\section{Songs}

This program used Jolly phonics song. This song program contains the sample song for all of the sounds in alphabetic letters. Example for the letter 's':

The snake is in the grass, the snake is in the grass.. 'sss '... 'sss'... 'sss'

The snake is in the grass

This song is sang by emphasizing the sound of the letter ' $\mathrm{s}$ ' in snake and the sound of hissing of snake which are quite similar. Singing this song also combined by an action of hand which copying the slithery move of the snake. The complete song can be referred to Jolly Phonics Songs.

\section{Games}

Children like playing; hence learning can be designed through playing as well. There are many games can be applied in phonic classes. Hunt the letter sound was one of them which applied many times in the classroom activities during the running of the program. When children start to be introduced to story books, during the classroom they can search the specific sounds pointed by teacher in the story. This way not only to enhance children's understanding the association between letter and its sound, but also the link between the letter sounds and words in book.

Picture clue could be another game can be played in the phonics class. There are cards with pictures on it. Students are asked to name the pictures and to mention the sounds on them. For example, there is a card with picture of car on it. The children asked to say the initial sound of the car, so the sound of ' $c$ '. Or in other way teacher asks to children:

"Can you see what picture is this? Can you guess what sounds are they?...or is there any 'c' sound on this picture?....". 
Matching pictures also can be quite useful for the reinforcement of learning the sounds and words. Teacher provides a lot of pictures and flash cards sheets of the sounds. Then teacher asked children to match the picture with the possibility of the sounds relate to the name of pictures. For example, the picture 'car' will be matched with the sounds of 'c', 'a', and ' $r$ '. By doing this teacher can explore not only the ability of students to recognize the initial sound of the name of thing but also even the ability to recognize all of the sounds to form the name/ word which is in other words called the ability of segmenting and blend them together to form the word.

\section{Word Box Sheets}

After students learn how to blend the sounds to form word, they will progress to the next step of word reading. Teachers need to provide a lot of sample words for word reading. They can use word boxes sheets. Word boxes can be made from the groups of words which are graded to progress from the simple words, using the first letter sounds taught, to more complicated words using digraphs. All of the words first taught are regular, so students can work the words out for themselves. Later, when they have learnt tricky words they can move to the irregular ones.

The use of word boxes has a goal to help students in blending practice which actually in real phonics program this can be done in class with the help of teachers and also at home with the help of parents.

\section{Storybooks}

Introducing storybooks can be valuable to teach children the function of reading skills and get them involved in engaging reading activities. Eventually, children gain in confidence in reading and can enjoy storybooks independently.

In reading session, teacher will read the book to children after each session of phonics and children supposed to see the printed words clearly and engage with it not just in terms of meaning but also in terms of looking at the words and eventually mentally figuring out how letters in words associates to sounds in speech (word reading). In this way, students will participate more in the activities. Later students encouraged to read the book their self with friend in group and stimulated to actively participate and discuss the issues in the book with their peers in group. In the end, students were given choice to choose the book and read it individually under the teacher guidance. Teacher may ask one student to go the front of the class and read the book for a whole of the class. Teacher will encourage and promote other students' participation in discussion of the topic. Teacher may also ask children to take the book home to read with parents. Thus, students were given most opportunities to develop their reading activities.

\section{CONCLUSION AND SUGGESTION}

The qualitative inquiry through observations, interviews and documentations revealed that phonics instruction models have gained good receptions from students. They keen to follow the fully program especially with the promising of plenty story books, nice songs and wide variety of activities. They declared that the instructional methods were easy to follow and the instructional materials were quite interactive. Their vigorous contributions in the classroom activities were a significant proof for the effectiveness of the program to improve students' participation in learning process.

However, there were some problems emerged in the instructional method. In the daily 
classroom practices, teachers were challenged to be able to apply this method so that it could be used within Indonesians socio-cultural context like large classrooms, the position of English as a foreign language, the custom of students learning in a traditional class with most of students usually took passive roles and the lack of teachers' skill in delivering this method. Problems also emerged for storybooks activities. Obviously this program needs collection of books or story books in English to be run smoothly. As a matter of fact, most of schools in Indonesia has limited collection of English books especially story ones.

To address the problems above, teacher may need training to deliver this program efficiently, also considering the fact that most of schools in Indonesian still have limited collection of English story books or any English books, the collaboration with government agencies or other promising bodies could be done to help in providing more collection of storybooks in schools.

\section{REFERENCES}

Acosta, Richelle L. 2012. An Exploration of Reading Methods in First-Grade: Comparing the Basal Approach and Balanced Literacy: A Dissertation. USA: Louisiana State University.

Adams, M. J. 1990. Beginning to Read: Thinking and Learning about Print. Cambridge, MA: MIT Press.

Adams, M. J., R. Treiman, and M. Pressley. 1998. "Reading, writing, and literacy". In handbook of Child Psychology 4, edited by I. E. Sigel and K. A. Renninger, 275-355. New York: Wiley.

Archer, Jennifer Aby. 2004. Characteristics of an Effective Teacher of Reading in an Elementary School Setting: A Dissertation. USA: Louisiana State University.

Bemhardt, E. E. 1991. Reading Development In a Second Language: Theoretical, Empirical \& Classroom Perspectives, New Jersey: Ablex Publishing Corporation.

Bloom, B. S. 1980. All Our Children Learning, New York: McGraw-Hill.

Borg, Walter R and Gall, Meredith D. 1983. Educational Research: An Introduction. New York: Longman.

Brooks, G. 1992. What teachers in training are taught about reading: the working paper, NFER Publishing: London.

Bums, A. and Coffin, C. 2001. Analysing English in a Global Context. New York: Rouflege Ltd.

Cambourne, B. L. 2002. In Farstrup, A. E. and S. J. Samuels (eds). Literature-based/constructivist approaches to reading and language arts instruction: What research has to say about reading instruction, 3rd edition, Newark, DE: International Reading Association, pp. 2547.

Cameron, Lynne. 2002. Teaching Languages to Young Learners. United Kingdom: Cambridge University Press.

Campbell, R. 1992. Reading Real Books, Buckingham. UK: Open University Press.

Chall, J. S. 1996. Learning to Read: The Great Debate. New York: McGraw-Hill.

Chall, J. S., and H. M. Popp. 1996. Teaching and Assessing Phonics: A Guide for Teachers. Cambridge, MA: Educator's publishing service. 
Clark Herbert H. and Eve V. Clark. 1977. Psychology and Language. New York: Harcourt Brace Jovanovich.

Chard, D. J., and J. Osborn. 1999. "Phonics and word recognition instruction in early reading programs: Guidelines for accessibility." Learning Disabilities Research and practice 14 (2): 107-117.

Cohen, L., Manion, L. 2003. Research Methods in Education, 5th Edition. London: Routledge/ Falmer Publication

Collins, J. W., 3rd, \& O'Brien, N. P. (Eds.). (2003). Greenwood Dictionary of Education. Westport, CT: Greenwood.

Cullinan, B. E. 1987. Children's Literature in the Reading Program, Newark, DE: International Reading Association.

Cullinan, B. E. 1992. Invitation to Read: More Children's Literature in the Reading Program, Newark, DE: International Reading Association.

Cummins, J. 2003. "Reading and the bilingual student: Fact and Fiction", In Garcia, G. (ed): Reaching the highest level of English literacy, Newark, DE: International Reading Association, pp. 2-33

Cresswell, J. W. 1994. Research Design: Qualitative and Quantitative Approaches, London: Sage Publications.

Crystal, D. 2003. English as a Global Language, Cambridge: Cambridge University Press.

Ehri, L. 1994. "Development of the ability to read words." In Theoretical Models and processes of Reading, edited by R. Ruddell, M. Ruddell, and H. Singer. Newark, DE: International Reading Association

Elley, W. B. and Mangubhal, F. 1983. The Impact of reading on second language learning, Reading Research Quarterly, 19: 53-67.

Fauziati, Endang. 2010. Teaching English as a Foreign Language (TEFL). Indonesia: Era Pustaka Utama.

Fauziati, Endang. 2009. Introduction to Methods and Approaches in Second or Foreign Language Teaching. Indonesia: Era Pustaka Utama.

Fauziati, Endang. 2009. Readings on Applied Linguistics: A Handbook for Language Teacher and Teacher Researcher. Indonesia: Era Pustaka Utama.

Ferguson, C. 1982. The Other Tongue: English across Cultures. Urbana: University of Illinois Press.

Fraenkel, J.R., Wallen, N.E., and Hyun, H.H. 2012. How to Design and Evaluate Research in Education. $8^{\text {th }}$ Edition. America: McGrawHill International Edition.

Gibbons, P. 1993. Learning to Learn in a Second Language, Newtown, NSW: Primary English Teachers Association.

Goodman, K. S. 1985. In Eds. Singer, H. and Robert, B. R., Unity in reading, Theoretical models and the processes of reading, 3rd edition. Newark, DE: International Reading Association.

Government of Australia, 2005. Teaching reading: A review of the evidence-based research literature on approaches to the teaching of literacy, particularly those that are effective in 
assisting students with reading difficulties, Canberra: Department of Education Science and Training.

Graham, J. 1990. Pictures on the Page, Sheffield: The National Association for the Teaching of English.

Harmer, Jeremy. 2005. How to Teach English: An Introduction to the Practice of English Language Teaching. Essex: Longman.

Holdaway, D. (1982). Shared book experience: teaching reading using favourite books. Sydney, NSW: Ashton Scholastic.

Hudelson, S. (1994). Literacy development of second language children. In F. Genesse, (Ed.), Educating second language children, pp. 129-158. New York: Cambridge University Press.

Hudelson, S. (1990). Bilingual/ESL learners talking in the English classroom. In S. Hynds \& D. L. Rubin (Eds.), Perspectives on talk and learning. pp. 267-283, Urbana, IL: National Council of Teachers of English

Hudelson, S. (1996). Children's Learning and the Design of English Teaching Programs. Pasto: Asocopi.

Holmgren, V. S. (1996). Elementary school counselling: An expanding role. Boston: Allyn and Bacon.

Kachru, B. 1992. The other Tongue: English across Cultures. Urbana: Illinois Press.

Krashen, S. D. 1996. Every person a reader: An alternative to the California Task Force report on Reading, Culver City, CA: Language Education Associates.

Kwan, A. B. and Willows, D. M. 1998. Impact of early phonics instruction on children learning English as a Second Language, Austin, Texas: National Reading Conference

Juel, C. 1994. Learning to Read in One Elementary School. New York: Springer-Verlag.

Juel, C. 1991. "Beginning reading." In Handbook of Reading Research 2, edited by R. Barr, M. hL. Kamil, P. B. Mosenthal, and P. D. Pearson. Mahwah, NJ: Erlbaum.

Lemons, Christopher J. 2008. Exploring the Effectiveness of Phonics-Based Instruction for Children with Down syndrome: A Dissertation. USA: Vanderbilt University

Mathes, P. G. and Torgesen, J. K. 2000. A call for equity in reading instruction for all students: A response to Allington and Woodside-Jiron, Educational Researcher, 29, 4-14.

McGuinness, D. 2004. Early Reading Instruction: What Science Really Tells Us about How to Teach Reading. MIT Press Cambridge, MA. UK.

McKay, S. L. 1993. Agendas for Second Language Literacy. Cambridge: Cambridge University Press.

McNamara, S. 1999. Differentiation: An Approach to Teaching and Learning. Cambridge: Pearson

Muro, J.J., \& Kottman, T. 1995. Guidance and counselling in the elementary and middle schools. Iowa: Brown and Benchmark.

National Reading Panel. 2000. Teaching Children to Read: An Evidence-based Assessment of the Scientific Research Literature on Reading and Its Implications for Reading Instruction. Bethesda, MD: National Institute of Child Health and Human Development 
Neuman, S. B. and Roskos, K. A. 1998. Children Achieving: Best Practices In Early Literacy. Newark: International Reading Association.

Nunan, D. 1994. Research methods in language learning. CUP.

Nuttall. C. 1996. Teaching Reading Skills in a Foreign Language, Oxford: Heinemann Publishing Ltd.

Patton, M. Q. 2002. Qualitative Research and Evaluation Methods. 3rd Edition. London: Sage Publications.

Pearson, D. 1993. Focus on Research: Teaching and Learning Reading (AResearch perspective), Language Arts, 502-511

Piaget, J. (1972). The Language and Thought of the Child. Ohio: World Publishing Company

Share, D., and K. E. Stanovich. 1995. "Cognitive processes in early reading development: Accommodating individual differences into a mode of acquisition." Issues in Education: Contributions for Educational Psychology 1: 1-57.

Silverman, D. 2000. Doing Qualitative Research: A Practical Handbook. London: Sage Publications

Smith, F. 1985. Reading. 2nd Edition. Melbourne: Cambridge University Press.

Smith, F. 1994. Understanding Reading. 5th Edition. Hillsdale, NJ: Lawrence Edbaum Associates.

Snow, C. E., Bums, M. S. and Gdffin, P. 1998. Preventing Reading Difficulties in Young children, Washington DC: National Academy Press

Stanovich, K. E. 1986. "Matthew effects in reading: Some consequences of individual differences in the acquisition of literacy." Reading Research Quarterly 21:360-407.

Thompson, G. B., Tunmer, W. E. and Nicholson, T. 1993. Reading Acquisition Processes. Clevedon: Multilingual Matters.

Torgesen, J. K., R. K. Wagner, and C. A. Rashotte. 1994. "Longitudinal studies of phonological processing and reading." Journal of Learning Disabilities 27: 276-286.

Vygotsky, L. S. 1978. Mind in society: The development of higher psychological processes. Chapter 6 Interaction between learning and development (79-91). Cambridge, MA: Harvard University Press.

Wahyuni, Naning. 2015. Developing Phonics-Based Combined with Book Reading Program in English Teaching Reading for Young Learners: Research and Development at Al Abidin International Islamic Elementary School Surakarta. A Thesis. Muhammdiyah University of Surakarta. Surakarta.

Watson, V. and Morag, S. 1996. Talking pictures: Pictorial texts and young readers. London: Hodder \& Stoughton

Wells, G. 1985. The meaning makers: Children learning language and using language to learn. Portsmouth, NH: Heinemann.

Wells, D. L., \& Langenfeld, G. P. (1999). Creating an Environment for Lifelong Learning. Paper presented at the ASEE Annual Conference \& Exposition. 